\title{
Geomorphic expression of late Quaternary sea level changes along the southern Saurashtra coast, western India
}

\author{
Nilesh BhatT* and Uday Bhonde \\ Department of Geology, Faculty of Science, M. S. University of Baroda, Vadodara 390 002, India. \\ *e-mail: nilesh_geol@yahoo.com
}

Geomorphic expression of land-sea interaction is preserved in the form of abandoned cliffs, marine terraces, shore platforms and marine notches along the southern Saurashtra coast. These features have been used to ascertain the magnitude of sea level changes during late Quaternary. Notch morphology and associated biological encrustation have been used to estimate the magnitude and duration of palaeo-sea strands. Marine notches and other erosive features occurring between 12 and $15 \mathrm{~m}$ above the present Biological Mean Sea Level (BMSL) are attributed to the last interglacial corresponding to the Marine Isotopic Stage 5 (MIS-5). However, 6 to $9 \mathrm{~m}$ upliftment of the coastal fringe is attributed to this sea level. The second major high sea strand was identified during the mid-Holocene when the sea rose $2 \mathrm{~m}$ above the present level. Notches corresponding to this high sea level are recorded 4 to $5 \mathrm{~m}$ above the present BMSL.

\section{Introduction}

The changing interface between land and sea during the late Quaternary period has attracted a large group of scientists and that has resulted into successive International Geological Correlation Programmes (IGCP - 61, 200, 274 and 367). The geomorphic studies carried out in different parts of the globe have successfully demonstrated that palaeo sea level can be estimated by marine notches, abandoned cliffs, superimposed notches and benches, sea caves and marine terraces. Of these, marine notches are now an established feature to study the past sea levels (Pirazzoli 1986; Pirazzoli et al 1996). The relative sea level changes along the Indian coast have been documented by several workers using different types of evidence, and sea level curves pertaining to the late Quaternary have been proposed (Kale and Rajaguru 1985; Hashimi et al 1995). The southern Saurashtra coast characterised by impressive cliffs and shore platforms, is an emergent type of coast (Ahmed 1972). A detailed record of the cliff profiles and associated geological features of the southern Saurashtra coast between Madhwad and Babarkot (figure 1) have been investigated here for reconstruction of the late Quaternary sea level.

\section{Study area}

The coastal segment lying between Kodinar and Babarkot is dominated by the textural variants of the bioclastic carbonate deposits (miliolite) of late Quaternary age (Bhatt 2003 and references therein). There occurs two distinct varieties referred to as miliolite limestone and shell limestone that form coastal sheets, beach ridges and associated aeolianites along with patchy occurrences of dead coral reefs. Stratigraphically, they are designated as the 'Miliolite Formation' and 'Chaya Formation' respectively, ranging in age from early Middle Pleistocene to Late Pleistocene (Bhatt 2003). The geochronology and field studies have ascertained the linkage of the shell limestone and associated aeolianites with the last interglacial

Keywords. Quaternary sea level; coastal geomorphology; marine notches; Gujarat. 

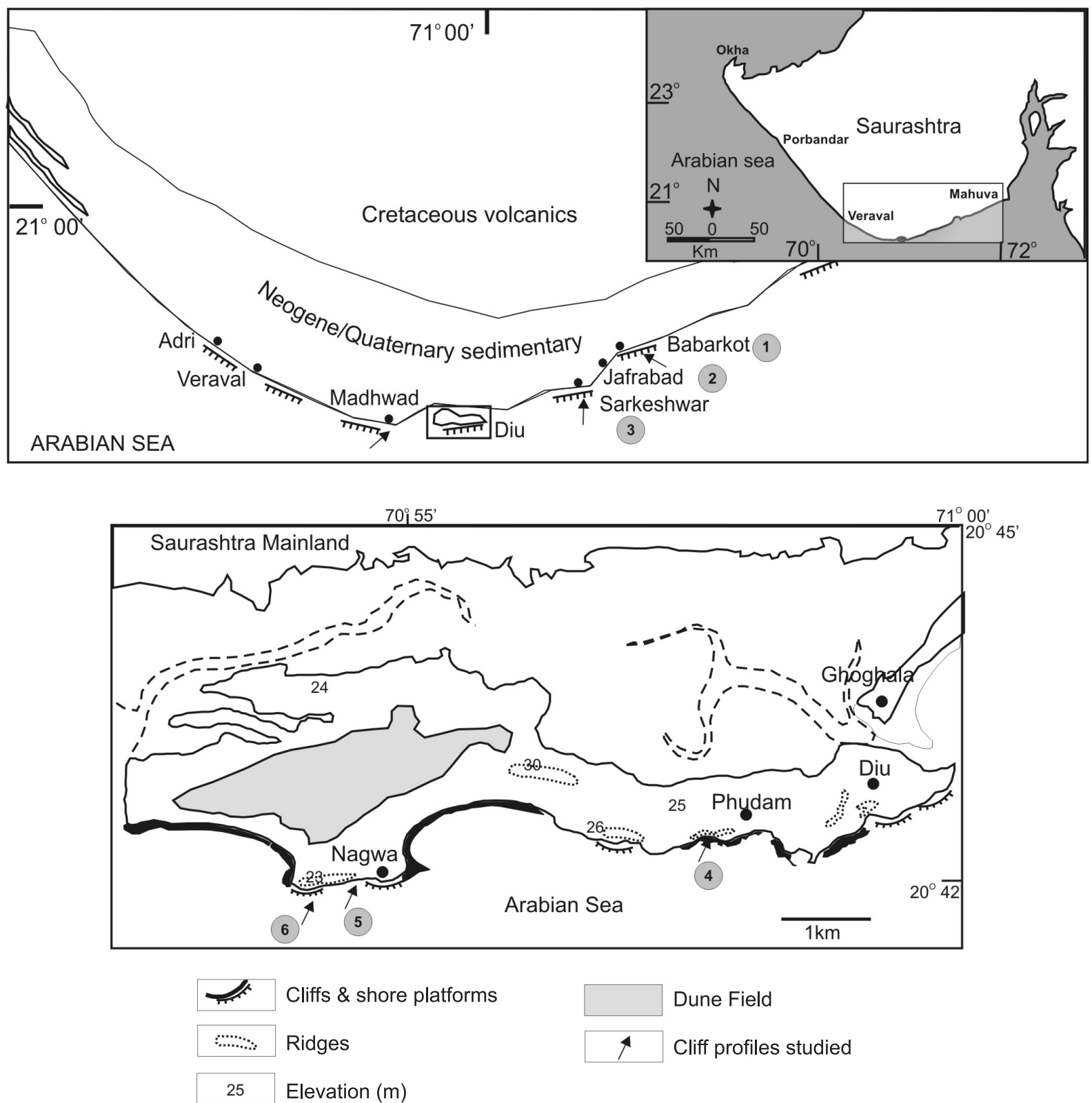

Figure 1. Map showing general coastal geomorphic features of south Saurashtra and locations of the cliff profiles studied. Lower box is an enlarged window of the Diu area.

high sea (Juyal et al 1995; Bhatt and Patel 1998; Mathur 2005). The underlying miliolite limestone unit thus predates the last interglacial. The cliff profiles studied are carved on the medium-tofine grained, relatively well sorted, cross-bedded miliolite limestone. These sequences have been formed by the successive stacking of the three major episodes of coastal carbonate deposition (Bhatt 2003). The oldest unit rests unconformably over the Gaj and Dwarka Formations of the MioPliocene age. This unit is recrystallised and pink in colour. Further it has been extensively pedogenised and karstified. About 1.5 m-thick red coloured soil usually separates this unit from the overlying porous and cross-stratified miliolite limestone unit.
This unit terminates with a thin duricrust that has a honeycomb appearance. An abraded, porous, friable and off-white coloured miliolite limestone unit finally overlies this duricrusted miliolite limestone unit.

\section{Marine notches - definition and mechanism}

Notches or nips are ' $U$ ' or ' $V$ ' shaped grooves, few centimetres to several metres deep, cut into the bed rocks and corresponding to the prevailing sea level. Their morphology (recumbent ' $U$ ' or ' $V$ ' shape) accords well with the tidal range (Pirazzoli 


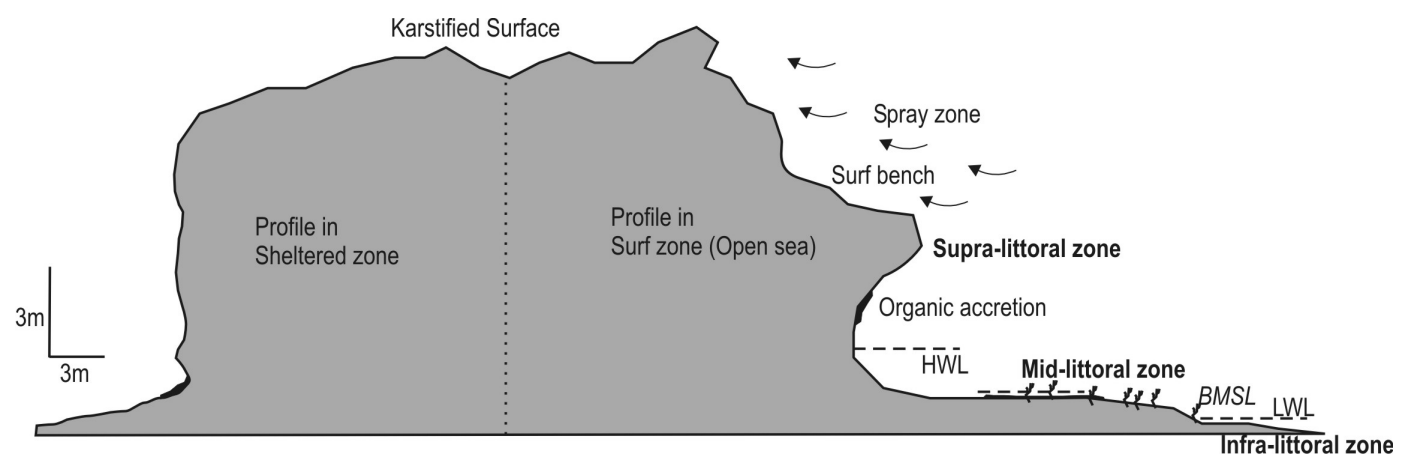

Figure 2. Schematic representation of the typical coastal cliff profile and its relation with the coastal bathymetric zones (after Rust and Kershaw 2000). HWL: High Water Line, LWL: Low Water Line and BMSL: Biological Mean Sea Level.

1986; Rust and Kershaw 2000). These features have received significant attention to enable the study of imprints of past sea levels. Recently, notches have been used to estimate land-sea interactions along the Mediterranean coastline (Pirazzoli 1986; Pirazzoli et al 1996; Rust and Kershaw 2000; Kershaw and Guo 2001).

From the process point of view, marine notches can be formed by a combination of physical, chemical and biological processes. Physical abrasion aided by sand and gravel enhances the process of marine notch formation giving rise to ' $\mathrm{U}$ ' or ' $\mathrm{V}$ ' shaped inundations that are easy to distinguish from the chemically or biologically formed notches by the development of a polished face on the notches (Rust and Kershaw 2000). Pirazzoli (1986) suggested that in addition to physical processes, biological activity in the form of bio-encrustation (algal and vermetid reef) plays an important role in the formation of marine/tidal notches. According to him the notches can develop in the infra-littoral zone which experiences complete immersion, the mid-littoral zone that is characterised by intermittent immersion and the supratidal zone that is above high tide level (figure 2). The infra-littoral and mid-littoral zones show a distinct difference in the amount and type of biomass. Their boundary has been regarded as Biological Mean Sea Level (BMSL) that can be used as dependable datum in the study of cliff profiles to interpret the past sea levels (Stiros et al 2000). As the tide range varies along the Saurashtra coast, the estimate of the mean sea level becomes difficult in the field. In view of this, the BMSL has been used as a standard datum in the present study.

A surf notch differs from a tidal notch. The surf notch occurs at higher elevations as it forms on the coasts exposed to the strong surf and spray actions characterised by the turbulent waters (Pirazzoli 1986). A surf notch profile is commonly asymmetric with a flat floor extending to the vertex which may be quite low in the notch profile.
The main criterion to distinguish a tidal notch from a surf notch is the absence of a surf bench in the former, while it is commonly associated with the latter. This surf bench is generally encrusted by the organic accretion (Rust and Kershaw 2000).

\section{Field occurrences}

The cliff profiles were studied in the field in prominent locations of south Saurashtra, and their geological and morphological details were systematically recorded. The study area was selected after a careful study of the Survey of India topographic sheets at 1:50,000 scale (figure 1). The coast line under study falls under micro-tidal to meso-tidal regime with a tide range from $1.8 \mathrm{~m}$ at Veraval to $2.54 \mathrm{~m}$ at Pipavav Port (near Jafrabad). The cliffs were visited during December-February and April-May months of the years 1999 to 2004 at maximum low tide and high tide times. The geographical locations and heights of the cliffs were measured using a Trimble make GeoExplorer-II Global Positioning System and a Barigo make Digital Altimeter having a maximum linearity error of $\pm 5 \mathrm{~m}$ in the range from 0 to $4000 \mathrm{~m}$. The GPS positions remained within 2 to $3 \mathrm{~m}$ from the actual. The altimeter has $1 \mathrm{~m}$ resolution and a measuring tape was used for sub-metre measurements.

\subsection{Babarkot-Jafrabad coastline}

A $10 \mathrm{~m}$ high cliff and associated head land at Babarkot $\left(20^{\circ} 52^{\prime} 06.65^{\prime \prime} \mathrm{N} ; 71^{\circ} 24^{\prime} 37.99^{\prime \prime} \mathrm{E}\right)$ has been described earlier by Pant and Juyal (1993) for its morphological features such as raised marine benches and distorted tidal notch. A record of cliff profile under present study indicates a prominent raised shore platform $3.5 \mathrm{~m}$ above the BMSL and an associated notch having $1.5 \mathrm{~m}$ roof height (figure 3A). The notch floor extends for more than $20 \mathrm{~m}$ along the cliff indicating a distinct raised 

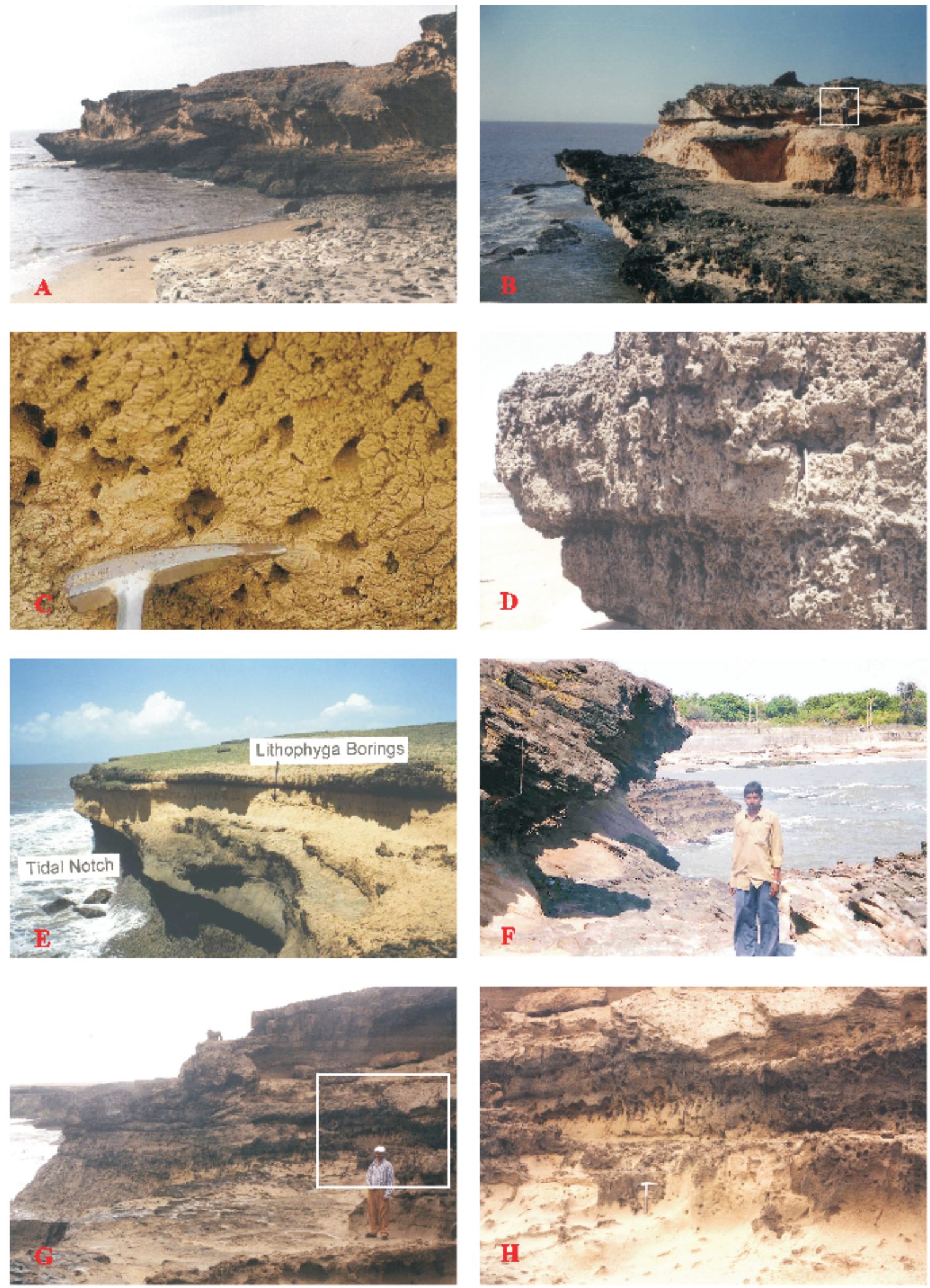

Figure 3. (A) A raised marine platform and associated notch at Babarkot. The cliff height from BMSL is $10 \mathrm{~m}$; (B) Active and ancient shore platforms encountered at Jafrabad light house (height of person 1.65 m); (C) Biological encrustation on the roof of a notch at Balana near Sarkeshwar (length of hammer head $10 \mathrm{~cm}$ ); (D) Bio-erosive marking on the recrystallised limestone unit near Sarkeshwar (length of the pen is $10 \mathrm{~cm})$; (E) Conspicuous level of Lithopaga borings as seen on about $8 \mathrm{~m}$ high shore platform near Nagwa, Diu (height of cliff is $14 \mathrm{~m}$ ); (F) A cliff near sunset point showing ancient marine notch with prominent roof and floor (height of a person is $1.65 \mathrm{~m}) ;(\mathbf{G})$ The highest occurrence $(15 \mathrm{~m}$ from BMSL) of shore platform in the study area near Madhwad west of Diu (height of a person $1.65 \mathrm{~m}$ ); $(\mathbf{H})$ A closer view of the window shown in $(\mathrm{G})$ showing the abraded nature of the platform and bio-erosive features (length of hammer shaft $30 \mathrm{~cm}$ ). 
shore platform. The vertex of the notch has a maximum of $0.6 \mathrm{~m}$ depth from the cliff face. Compact recrystallised miliolite limestone unit with highangle cross stratification and minor breaks in the foresets forms the lithology of the cliff. The notch face is moderately polished and lacks biological features like borings or encrustation.

The miliolite limestone cliff at Jafrabad lighthouse exhibits a distinct shore platform at the height of $4 \mathrm{~m}$ from BMSL extending for a maximum of $3.8 \mathrm{~m}$ seawards. This platform abuts against a $3 \mathrm{~m}$-high cliff face and a remnant of a notch showing $2.4 \mathrm{~m}$ roof height and $1.5 \mathrm{~m}$ depth at vertex. The raised platform hangs over the present-day notch which also has its floor extended for a considerable width shaping out a shore platform (figure 3B). The cliff making miliolite limestone unit is identical to that of Babarkot and is capped by a relatively steep tabular cross-bedded younger miliolite limestone unit.

About $3 \mathrm{~km}$ westward at Balana near Sarkeshwar temple $\left(20^{\circ} 50^{\prime} 07.26^{\prime \prime} \mathrm{N} ; 71^{\circ} 17^{\prime} 51.69^{\prime \prime} \mathrm{E}\right)$ the coast has a cuspate beach abutting against a moderate cliff that remains above HWL for a major part of the year. This $8 \mathrm{~m}$-high cliff preserves a notch at a height of $4.3 \mathrm{~m}$ above BMSL. The notch vertex is $0.75 \mathrm{~m}$ deep and the roof height is $0.5 \mathrm{~m}$ from the notch floor. An important feature of this notch is well preserved floral pattern biological encrustation of sea weed/marine algae (figure 3C) as are commonly found in the sheltered sites. Presently the site is isolated from modern coastal processes. The lithology of the cliff is at variance from the adjacent sites, and comprises porous, coarse grained, planer cross-bedded miliolite limestone with mega shell fragments of gastropods and pelecypods, barnacles and older limestone gravels. Stratigraphically, this unit is correlatable with the shell limestone unit corresponding to the MIS- 5 high sea that occurs all along the southwestern Saurashtra coast lying over the recrystallised older miliolite limestone unit with an erosional surface in between (Bhatt and Patel 1998). In a nearby locality (200 m west of the Sarkeshwar temple), on an $8 \mathrm{~m}$-high older miliolite limestone cliff a surf notch at $4 \mathrm{~m}$ above BMSL is seen without biological encrustation. Similarly, about $50 \mathrm{~m}$ eastwards from the temple, a $3 \mathrm{~m}$-high recrystallised miliolite limestone cliff buried under the coastal dune sand has bio-erosive features (figure 3D).

\subsection{Diu and adjacent coastline}

On Diu island, the most prominent cliff profile has been recorded near Nagwa $\left(20^{\circ} 42^{\prime} 01.53^{\prime \prime} \mathrm{N}\right.$; $\left.70^{\circ} 54^{\prime} 33.06^{\prime \prime} \mathrm{E}\right)$. Here, the cliff is about $14 \mathrm{~m}$ in height and is made up of pink coloured compact and recrystallised miliolite limestone unit. About
$8 \mathrm{~m}$ above the BMSL an older shore platform has a weakly developed notch like feature (figure $3 \mathrm{E}$ ). The base of the notch extends for about $3 \mathrm{~m}$ towards the sea and contains significant lithophaga borings. The borings range in diameter from 0.5 to $3 \mathrm{~cm}$ and are similar to one found near the high water line. About $300 \mathrm{~m}$ westward from this place $\left(20^{\circ} 42^{\prime} 11.66^{\prime \prime} \mathrm{N} ; 70^{\circ} 53^{\prime} 55.87^{\prime \prime} \mathrm{E}\right)$ another cliff of about $3.5 \mathrm{~m}$ height made up of the porous miliolite limestone unit hosts a number of biogenic structures in the form of burrows of about 0.5 to $1 \mathrm{~m}$ length and 1 to $2 \mathrm{~cm}$ in diameter. The concentration of biogenic structures decreases above $3 \mathrm{~m}$ and the miliolite limestone unit becomes more compact and homogenous. The boundary between these two units is marked by a karstified surface. The cliff has preserved a notch at a height of 3.2 to $3.5 \mathrm{~m}$ above BMSL which is above the present day tidal influence.

Near the Gangeshwar temple $\left(20^{\circ} 42^{\prime} 11.81^{\prime \prime} \mathrm{N}\right.$; $70^{\circ} 57^{\prime} 18.27^{\prime \prime} \mathrm{E}$ ), a cliff of about $15 \mathrm{~m}$ height exhibits two different varieties of miliolite limestone units, viz., very fine grained compact recrystallised unit up to the height of $10 \mathrm{~m}$ and about 3 to $4 \mathrm{~m}$ thick medium-to-coarse grained thinly laminated and highly bioturbated younger unit lying above. These two units are separated from each other by almost a meter thick red soil. Convolute laminations are conspicuous in the younger miliolite limestone unit at this site. Near the sunset point the cliff attains a height of almost 5 to $6 \mathrm{~m}$ and is made up of fine grained compact miliolite limestone unit, with beds dipping towards the sea. The upper part of the cliff up to $2.5 \mathrm{~m}$ above the present day BMSL shows burrow and pipe like structures hanging from the roof of the notch, while the floor of the notch is relatively flat and abraded/polished (figure $3 \mathrm{~F}$ ).

On the western side of the tidal channel separating Diu island from the mainland Saurashtra, a prominent cliff of about $20 \mathrm{~m}$ height was studied at Madhvad $\left(20^{\circ} 41^{\prime} 23.42^{\prime \prime} \mathrm{N} ; 70^{\circ} 49^{\prime} 37.38^{\prime \prime} \mathrm{E}\right)$. The cliff is mainly composed of the recrystallised and cross-bedded miliolite limestone unit identical to that at the Nagwa on Diu island. Occurrence of prominent raised shore platform at about $15 \mathrm{~m}$ height above BMSL exhibits abraded and polished nature, and also a level of biological erosion at $70 \mathrm{~cm}$ above the floor of the platform (figure $3 \mathrm{G}$ and $\mathrm{H}$ ) that can be traced for more than $20 \mathrm{~m}$. Figure 4 presents the cliff profiles studied and described above.

\section{Discussion}

Evidences from continents for sea level changes during the late Quaternary include occurrences of 

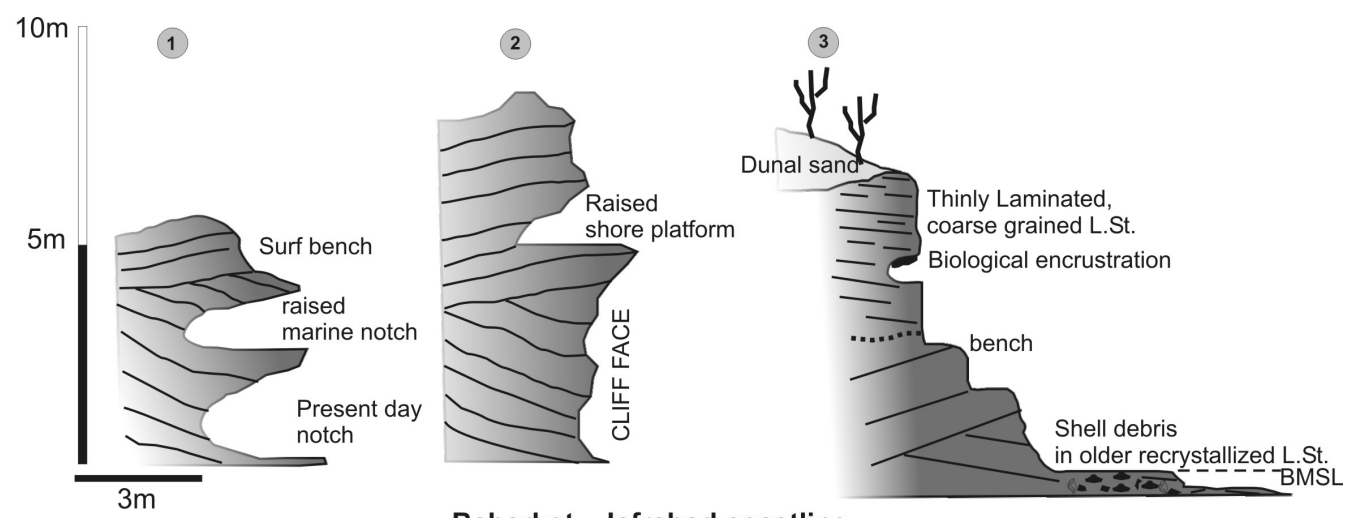

Babarkot - Jafrabad coastline

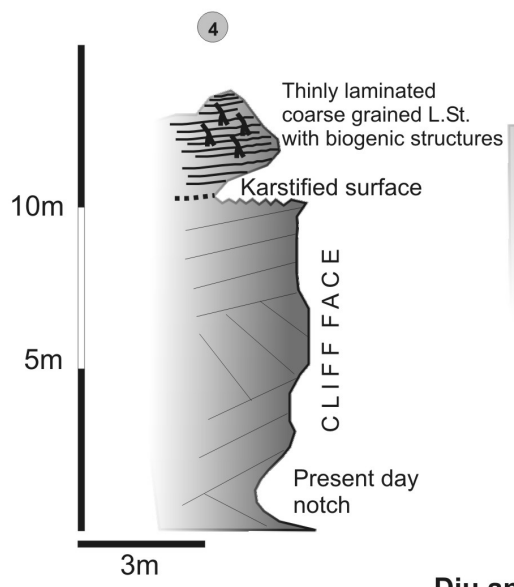

(5)
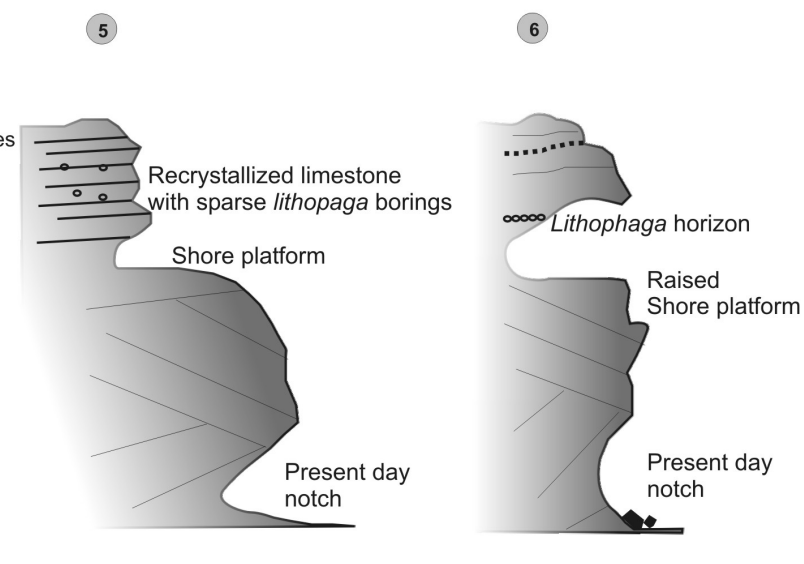

Diu and adjacent coastline

Figure 4. Summary of the coastal cliff profiles studied and described from southern Saurashtra. The numbers have reference to the locations shown in figure 1.

depositional and erosional events. The Gujarat and Maharashtra coastal segments have been studied in this regard (Brückner 1989; Patel 1991). The presence of coast parallel beach ridges, aeolianites, higher occurrences of dead coral reefs, shell limestone and tidal flats, and also other geomorphic features suggest an oscillating late Quaternary sea level along the Saurashtra coast. The available geochronological data obtained on coral reefs and oyster from the Saurashtra coast indicate the existence of two major high sea strands corresponding to the last interglacial (MIS-5) and midHolocene (Gupta and Amin 1974; Brückner et al 1987; Juyal et al 1995; Mathur and Pandey 2002; Mathur 2005). These chronometric data compared with coastal geomorphic features of sea level changes suggest that the last interglacial (MIS-5) high sea strands had eroded the pre-existing miliolite limestone sequences and deposited the bioclast rich beach ridges and associated dunes including the favored growth of coral reefs in suitable coastal segments (Bhonde 2004).

The coastal geomorphic system has a tendency to adjust with the changing land-sea level positions and is manifested in depositional and erosional landforms. However, compared to the erosional landforms that require a long residence time of sea, the depositional landforms can be generated in episodic storm surge events. Therefore, the usage of shell beds or beach ridges may at times be mistaken for palaeo-strand line reconstruction.

The present study indicates occurrence of prominent notches at 4 to $5 \mathrm{~m}$ elevation from the present day BMSL around Jafrabad and Babarkot area (figure 4). The depths of vertices clearly indicate a long duration of the strand. In contrast to this, the highest occurrence of such a prominent notch and platform along with the biological erosive marks in Diu area reach 12 to $15 \mathrm{~m}$ above BMSL. In addition to this, less prominent notches at an elevation of $5 \mathrm{~m}$ have also been observed (figure 4). As described earlier, the notch occurrence at Balana near Sarkeshwar is found associated with the younger miliolite limestone unit that is stratigraphically correlatable with the MIS- 5 high sea. These suggest that the notches occurring at 4 to $5 \mathrm{~m}$ elevation post date the last interglacial. The depositional units corresponding to this high sea level are found in the adjacent areas occurring above the older recrystallised miliolite limestone unit with an 
erosional contact (Juyal et al 1995; Bhonde 2004). It appears that the highest notch occurrences in Diu area were formed during the last interglacial high sea along with the benches and terraces in the Jafrabad and Babarkot area because, they are developed in an older miliolite limestone unit that forms the substrate to the shell limestone and miliolite units of the MIS- 5 in the region. Moreover, Baskaran et al (1989) have reported the ${ }^{230} \mathrm{Th} /{ }^{234} \mathrm{U}$ age of Diu miliolite to be $178(+41$ and -28$)$ ka (sample no. 37). Even if it has been underestimated due to post-depositional recrystallisation, the cliff-making miliolite limestone of Diu must be older than the MIS-5. The observation accords well with Pant and Juyal (1993) that after the last interglacial the area has upthrown by 8 to $9 \mathrm{~m}$. In view of this the lower notch occurrences at 4 to $5 \mathrm{~m}$ would suggest its formation during the Holocene (MIS-1) transgression. Using the ${ }^{14} \mathrm{C}$ ages of Cerithium and Turbo from Porbandar and Mithapur area, Mathur et al (2004) invoked a 2 to $3 \mathrm{~m}$ higher mid-Holocene sea that had a falling trend since. The ages of oyster reefs occurring in Rupen river bed, north of Diu also indicate a $2 \mathrm{~m}$ higher sea at 2.5 and $3.3 \mathrm{ka}$ (Juyal et al 1995). The oyster bed occurring at $1 \mathrm{~m}$ AMSL near Khada Bandar has yielded a $3.47 \pm 0.11 \mathrm{ka}{ }^{14} \mathrm{C}$ age. This suggests the Holocene high sea level of about $2 \mathrm{~m}$ in Saurashtra which correlates well with the global sea level of this time. However, the occurrence of notches and associated features at 4 to $5 \mathrm{~m}$ elevation and also notches related to the present day sea level just below these, suggest a rapid fall in the sea level that can be accounted for by uplift of the coastal cliffs of the order of $2 \mathrm{~m}$ over 3 ka. Following this, the sea level was stabilised at its present position as indicated by the development of the modern notches.

\section{Conclusion}

The cliffy coast of southern Saurashtra has preserved a record of the sea level changes during the late Quaternary. Based on the geomorphic positions of the notches two major palaeo-sea strands have been identified. The older sea strand lies at an elevation ranging from 12 to $15 \mathrm{~m}$ above the present BMSL and has been attributed to the last interglacial (MIS-5). Following this, a major tectonic upthrow of about 6 to $9 \mathrm{~m}$ was experienced by the southern cliffy coast. The Holocene sea level was recorded at 4 to $5 \mathrm{~m}$ which is about $2 \mathrm{~m}$ higher than the general MIS-1 sea level. These data are in accordance with the regional sea level curves obtained from other parts of the globe.

\section{Acknowledgements}

The present work has been carried out under a Department of Science and Technology (Government of India) supported research project No. ESS/23/VES/019/98. The Department of Geology, M. S. University of Baroda is acknowledged for its infrastructural facilities. Constructive suggestions from Dr. Navin Juyal and an anonymous reviewer have greatly improved the original version. Dr. Hetu Sheth is gratefully acknowledged for the editorial comments.

\section{References}

Ahmed E 1972 Coastal Geomorphology of India (New Delhi: Orient Longman) p. 222.

Baskaran M, Rajagopalan G and Somayajulu B L K 1989 ${ }^{230} \mathrm{Th} /{ }^{234} \mathrm{U}$ and ${ }^{14} \mathrm{C}$ dating of the Quaternary carbonate deposits of Saurashtra, India; Chem. Geol. (Isot. Geosci. Sect.) 79 65-82.

Bhatt N 2003 Quaternary carbonate deposits of Saurashtra and Kachchh, Gujarat, Western India: A Review; Proc. Indian Nat. Sci. Acad. 69 137-150.

Bhatt N and Patel M P 1998 Bioclastic shore deposits: indicators of late Quaternary high sea in Saurashtra, western India; J. Geol. Soc. India 52 537-542.

Bhonde U A 2004 late Quaternary geomorphic evolution of the southwestern Saurahstra coast, Gujarat, India; (Unpubl.) Ph.D. Thesis, M. S. University of Baroda, Vadodara.

Brückner H, Montaggioni L and Rescher K 1987 Miliolite occurrence on Kathiawar peninsula (Gujarat), India: Latest results from chronostratigraphical, petrological and palaeozoological analysis; Berliner Geographishce Studies 25 343-361.

Brückner H 1989 late Quaternary shorelines in India; In: Late Quaternary sea-level correlation and application; (eds) Scott D B, Pirazzoli P A and Honig C A, Kluwer Academic Publishers, pp. 169-194.

Gupta S K and Amin B S 1974 Io/U ages of corals from Saurashtra coast; Marine Geol. 16 79-83.

Hashimi N H, Nigam R, Nair R R and Rajagopalan G 1995 Holocene sea level fluctuations on western India continental margin: An update; J. Geol. Soc. India 46 157-162.

Juyal N, Pant R K, Bhushan R and Somayajulu B L K 1995 Radiometric dating of late Quaternary sea levels of the Saurashtra coast, Western India: An experiment with oyster and clam shells; Geol. Soc. India Memoir 32 372-379.

Kale V S and Rajaguru S N 1985 Neogene and Quaternary transgressional and regressional history of the west coast of India; Bull. Deccan College Res. Inst. 44 $153-165$.

Kershaw S and Guo L 2001 Marine notches in coastal cliffs: Indicators of relative sea-level change, Perachora peninsula, central Greece; Marine Geol. 179 213-228.

Mathur U B 2005 Quaternary Geology: Indian Perspective; Geol. Soc. India Memoir 63344.

Mathur U B and Pandey D K 2002 Radiocarbon dates of corals, gastropods and foraminifers from Saurashtra peninsula, Gujarat and their implications for sea level studies; J. Geol. Soc. India 60 303-308. 
Mathur U B, Pandey D K and Tej Bahadur 2004 Falling Late Holocene sea level along Indian coast; Curr. Sci. 87 439-440.

Pant R K and Juyal N 1993 Late Quaternary coastal instability and sea level changes: New evidences from Saurashtra coast, Western India; Zeitschirft für Geomorphologie 37 29-40.

Patel M P 1991 Quaternary strandlines in Gujarat; In: Proc. Quat. Landscape of Indian Subcont. (eds) Desai N, Ganapathi S and Patel P K; M. S. Univeristy of Baroda, pp. 107-118.

Pirazzoli P A 1986 Marine Notches; In: Sea-level Research: a manual for the collection and evaluation of data; (ed.) Van de Plassche O, Geo Books Norwich UK, 361-400.

Pirazzoli P A, Bellevue M, Laborel J and Stiros S C 1996 Coastal indicators of rapid uplift and subsidence: examples from Crete and other eastern Mediterranean sites; Zeitschrift für Geomorphologie 102 21-35.

Rust D and Kershaw S 2000 Holocene tectonic uplift pattern in northern Sicily: Evidence from marine notches in coastal outcrops; Marine Geol. 167 105-126.

Stiros S C, Laborel J, Laborel-Deguen F, Papageorgiou S, Evin J and Pirazzoli P A 2000 Seismic coastal uplift in a region of subsidence: Holocene raised shorelines of Samos Island, Aegen Sea, Greece; Marine Geol. 170 41-58. 